\title{
TUGAS AKHIR HUKUM PERBANKAN SYARIAH
}

Kelompok 1: GAMBARAN UMUM PERBANKAN NASIONAL

A. Pengertian Bank

1. Pengertian Bank menurut Para Ahli

2. Pengertian Bank Menurut Undang Undang.

B. Sejarah Perbankan Nasional

1. Sebelum Kemerdekaan

2. Setelah Kemerdekaan

C. Hukum Perbankan

Kelompok 2: KEDUDUKAN BANK SYARIAH DALAM SISTEM PERBANKAN DI INDONESIA
A. Sejarah Singkat Perbankan Syariah di Indonesia
B. Satu Negara dengan Dua Sistem Perbankan
C. Dasar Hukum Perbankan Syariah di Indonesia
D. Perkembangan Bank Syariah di Indonesia

Kelompok 3: PRINSIP-PRINSIP HUKUM PERBANKAN SYARIAH
A. Asas Demokrasi Ekonomi (Economic Democracy Principles)
B. Prinsip Syariah (Sharia Principles)
C. Prinsip Kehati-hatian Bank (Prudential Banking)
D. Prinsip Mengenal Nasabah (Know Your Costumer Principles)
E. Prinsip Kepercayaan (Fiduciary Principle) 
F. Prinsip Kerahasiaan (Secrecy Principle)

\section{Kelompok 4: AKAD-AKAD DAN PRODUK-PRODUK PERBANKAN SYARIAH}

A. Pengertian Akad dan Jenis-jenis Akad Bank Syariah

1. Akad Wadi'ah

2. Akad Mudharabah

3. Akad Musyarakah

4. Akad Murabahah

5. Akad Salam

6. Akad Istishna

7. Akad Ijarah

8. Akad Qardh

B. Produk-produk Perbankan Syariah

1. Penghimpunan Dana

2. Penyaluran Dana (Pembiayaan)

3. Jasa Perbankan Syariah Lainnya

C. Inovasi dalam Produk-Produk Perbankan syariah

1. Anjungan Tunai Mandiri Bank Syariah

2. Kartu Multi Akses Bank Syariah

3. Layanan Call Center Bank Syariah

4. SMS Banking, Internet Banking dan Mobile Banking berbasis Aplikasi 
Kelompok 5: FATWA-FATWA DEWAN SYARIAH NASIONAL MAJELIS ULAMA INDONESIA (DSN-MUI)
A. Pengertian Fatwa dan Fatwa Dewan Syariah Nasional Majelis Ulama Indonesia
B. Dewan Syariah Nasional Majelis Ulama Indonesia (DSN-MUI)
C. Fatwa-Fatwa Terkait Perbankan Syariah

Kelompok 6: MANAJEMEN RISIKO PERBANKAN SYARIAH

A. Pengertian Risiko Perbankan

B. Jenis-jenis Risiko Perbankan Syariah

1. Risiko Pembiayaan (financing risk)

2. Risiko Pasar (market risk)

3. Risiko Operasional (operational risk)

4. Risiko Hukum (legal risk)

5. Risiko Likuiditas (liquidity risk)

6. Risiko Strategi (strategic risk)

7. Risiko Reputasi (reputation risk)

8. Risiko Kepatuhan (compliance risk)

9. Risiko Imbal Hasil (Rate of Return Risk)

10. Risiko Investasi (Equity Investment Risk)

C. Manajemen Risiko

1. Kesiapan Struktural Bank Syariah

2. Analisis Risiko 
3. Fitur Umum Sistem Peringatan Dini

\section{Kelompok 7: PENGAWASAN PERBANKAN SYARIAH}

A. Pengawasan Internal Perbankan Syariah

1. Pengawasan oleh Dewan Komisaris Bank Syariah

2. Pengawasan oleh Jajaran Direksi

3. Pengawasan oleh Dewan Pengawas Syariah (DPS)

B. Pengawasan Bank Syariah oleh Otoritas Jasa Keuangan (OJK)

C. Peranan Bank Indonesia

Kelompok 8: TINDAK PIDANA DALAM LINGKUNGAN PERBANKAN

A. Tindak Pidana Pencucian Uang (money laundering)

1. Transaksi Keuangan Mencurigakan (Suspicious Transaction)

2. Harta Kekayaan dari Hasil Tindak Pidana Pencucian Uang

3. Sanksi Pidana TPPU

4. Peranan PPATK

B. Pembiayaan Fiktif

C. Pencairan Dana Nasabah secara Ilegal

D. Ketentuan Pidana dalam Undang-undang Perbankan Syariah

Kelompok 9: PENYELESAIAN SENGKETA PERBANKAN SYARIAH

A. Penyelesaian Sengketa di Pengadilan (Jalur Litigasi)

1. Dasar Hukum

2. Pelaksanaan Kewenangan Pengadilan Agama dalam Sengketa Ekonomi Syariah 
B. Penyelesaian Sengketa di Luar Pengadilan (jalur non litigasi)

1. Penyelesaian Sengketa Secara Internal dalam Bank Syariah

2. Penyelesaian Sengketa melalui mekanisme Pengaduan ke OJK

3. Penyelesaian Sengketa melalui Badan Arbitrase Syariah Nasional (Basyarnas)

C. Studi tentang Kasus Hukum Perbankan Syariah di Indonesia

Kelompok 10: MEWUJUDKAN TATA KELOLA PERBANKAN SYARIAH YANG SEHAT DAN DINAMIS

A. Tata Kelola Perusahaan yang Baik (good corporate governance)

1. Transparansi (transparency)

2. Kemandirian (independency)

3. Akuntabilitas (accountability)

4. Pertanggungjawaban (responsibility)

5. Kewajaran (fairness)

B. Penilaian Tingkat Kesehatan Bank Syariah

1. Permodalan (Capital)

2. Kualitas Aset (Asset Quality)

3. Kualitas Manajemen (Management Quality)

4. Aspek Likuiditas (Liquidity)

5. Aspek Rentabilitas (Rentability)

C. Mewujudkan Industri Perbankan Syariah yang Sehat dan Dinamis

D. Dukungan Lembaga Penjamin Simpanan (LPS) 


\section{Contoh:}

\section{GAMBARAN UMUM PERBANKAN NASIONAL}

$\begin{array}{ll}\text { Kelompok } & : 1 \\ \text { Nama Peserta } & : 1 . \\ & 2 . \\ \text { Tugas Akhir } & : \text { Hukum Perbankan Syariah } \\ \text { Semester } & : \text { IV } \\ \text { Prodi } & : \text { Hukum Ekonomi Syariah }\end{array}$

A. Pengertian Bank

1. Pengertian Bank menurut Para Ahli

2. Pengertian Bank Menurut Undang Undang.

Kesimpulan point A: Menggunakan Bahasa Sendiri berdasarkan pemahaman, dibuat dalam satu alinea, dengan format huruf tebal keseluruhan dimulai dari kata "Kesimpulan"

B. Sejarah Perbankan Nasional

1. Sebelum Kemerdekaan

2. Setelah Kemerdekaan

$\underline{\text { Kesimpulan point B: Menggunakan Bahasa Sendiri berdasarkan pemahaman, dibuat dalam satu }}$ alinea, dengan format huruf tebal keseluruhan dimulai dari kata "Kesimpulan"

C. Hukum Perbankan

$\underline{\text { Kesimpulan point C: Menggunakan Bahasa Sendiri berdasarkan pemahaman, dibuat dalam satu }}$ alinea, dengan format huruf tebal keseluruhan dimulai dari kata "Kesimpulan"

Daftar Pustaka : dibuat dengan format daftar pustaka, bukan format footnote. 
Format Penulisan :

1. Paper Size : A4

2. Margin $: 4 \mathrm{~cm}$ (Atas dan Kiri), $3 \mathrm{~cm}$ (kanan dan bawah)

3. Page number : Times New Roman (diletakkan Sudut kanan atas), 10 pt

4. Font : Times New Roman

5. Font size : $12 \mathrm{pt}$

6. Footnote : Times New Roman, $10 \mathrm{pt}$

7. Rata teks : disesuaikan

8. Line Spacing : 1.5

\section{Pengumpulan Tugas:}

Dikirim ke email: adriandikasim@iain-manado.ac.id dalam format Microsoft word paling lambat 1 jam sebelum UAS dimulai 